\title{
Starting Performance Analysis for Universal Motors by FEM
}

\author{
Kazumi Kurihara Senior Member (Ibaraki University, kurihara@mx.ibaraki.ac.jp) \\ Shin-ichi Sakamoto Member (Hitachi Koki Co., Ltd., sakamoto-s@hitachi-koki.co.jp)
}

Keywords: universal motor, starting characteristics, finite element method

This paper presents a novel transient analysis of the universal motors taking into account the time-varying brush-contact resistance and mechanical loss. The transient current, torque and speed during the starting process are computed by solving the electromagnetic, circuit and dynamic motion equations, simultaneously. The computed performances have been validated by tests in a 500-W, 2-pole, $50 \mathrm{~Hz}, 100 \mathrm{~V}, 8.0 \mathrm{~A}, 19200 \mathrm{~min}^{-1}$ universal motor.

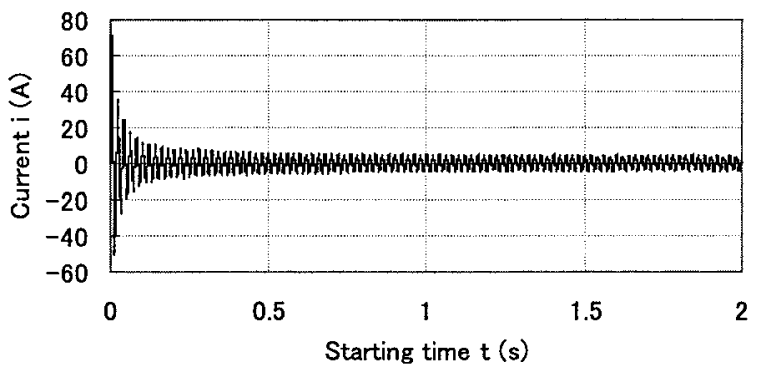

(a) Computed armature-current

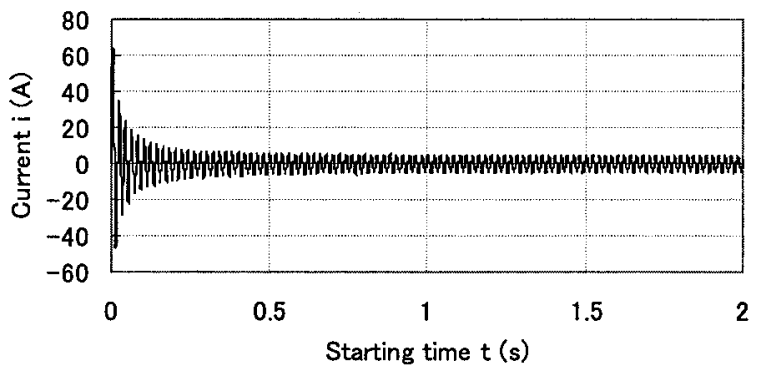

(b) Measured armature-current

Fig. 1. Armature current during run-up at AC90 V

Fig. 1(a) and (b) shows the computed and measured armature currents versus time during run-up at $\mathrm{AC} 90 \mathrm{~V}$ close to the rated voltage. It is shown that the agreement between the computed and measured results is good.

Fig. 2(a) and (b) shows the computed and measured speed versus time during run-up at $\mathrm{AC} 90 \mathrm{~V}$. It is shown that the agreement between the computed and measured results is good.

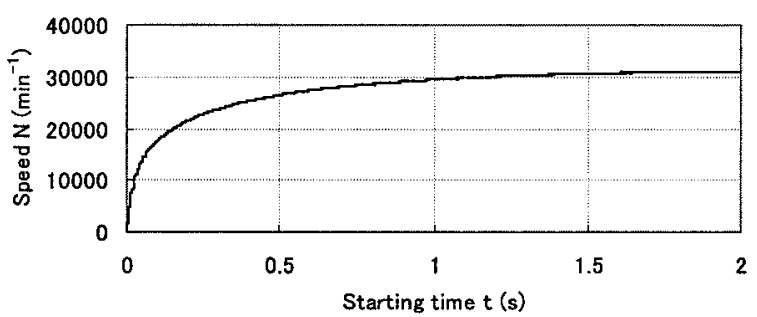

(a) Computed speed response

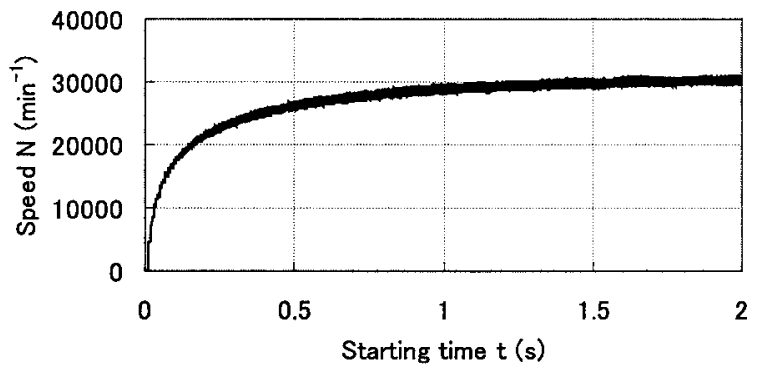

(b) Measured speed response

Fig. 2. Speed during run-up at AC90 V

A novel transient performance analysis of the universal motors taking into account the time-varying brush contact resistance and mechanical loss has been presented for the first time. Reasonably good agreements between the computed and measured results of a $500-\mathrm{W}, 2$-pole universal motor confirm the validity of the proposed analysis. 


\title{
FEMによるユニバーサルモータの始動特性解析
}

\author{
上級会員 栗原 和美* 正 員 坂本 眞一**
}

\section{Starting Performance Analysis for Universal Motors by FEM}

Kazumi Kurihara*, Senior Member, Shin-ichi Sakamoto**, Member

This paper presents a novel transient analysis of the universal motors taking into account the time-varying brushcontact resistance and mechanical loss. The transient current, torque and speed during the starting process are computed by solving the electromagnetic, circuit and dynamic motion equations, simultaneously. The computed performances have been validated by tests in a 500-W, 2-pole, $50 \mathrm{~Hz}, 100 \mathrm{~V}$ universal motor.

キーワード : ユニバーサルモータ, 始動特性, 有限要素法

Keywords: universal motor, starting characteristics, finite element method

\section{1. まえがき}

ユニバーサルモータの多くは, 電動工具及び家電機器に 使用されている。これは，この種の電動機が，他種の商用 電源駆動の電動機に比較して, 構造が簡単で堅牢, 小型化· 軽量化及び高速化が容易で，始動トルクが大きいなどの特 長を有するからである。しかし, 小形化・軽量化が一段と 進むと, 始動トルクの低下や脈動トルクによる振動・騒音 の問題が生じてくる。これらの問題を解決するには, 設計 段階において，ユニバーサルモータの始動特性を正確に把 握する必要がある。ところが, 回転とともに変化する整流 や回転損失があるため, ユニバーサルモータの過渡特性解 析は非常に難しい。特に, 始動時の場合, 電源投入直後の 電機子巻線の逆起電力が零であるので, 過渡時の電機子電 流は定常時の数倍以上に達する。このため, 整流中の整流 コイルの電流（短絡電流）変化も大きく, 瞬時の回転子位 置における電機子電流，整流電流を，電機子反作用 ${ }^{(1)}$, 磁 気飽和, 短絡電流による磁界の影響を考慮した㛜密な解析 から求める必要がある。また，始動時の速度応答を解析す る場合, 瞬時の回転子位置を求める必要があり, 一般には 運動方程式 (2) を解いて回転子の位置情報を得ている。ここ で，運動方程式中の瞬時トルクを如何に正確に求めるかが 鍵になっている。この瞬時トルクは, 電機子電流, 整流電

\footnotetext{
*茨城大学

厂 316-8511 日立市中成沢町 4-12-1

Dept. of Electrical and Electronic Eng., Ibaraki University

4-12-1, Nakanarusawa, Hitachi 316-8511

** 日立工機（株）

テ312-8502 ひたちなか市武田 1060

Hitachi Koki Co., Ltd.

1060, Takeda, Hitachinaka 312-8502
}

流同様, 電機子反作用, 磁気飽和, 短絡電流による磁界の 影響を考慮した厳密な解析から求める必要がある。

著者の一人は既に, 自己始動形永久磁石同期電動機の過 渡特性解析において, 電磁界方程式, 回路方程式, 運動方 程式を連成した有限要素法による解析法を確立し, その有 用性を確認している (3)。ユニバーサルモータの始動特性解 析に, 前述の有限要素法による解析法を適用するときに問 題となるのは次の三点である。一つは, 短絡電流を求める ための整流方程式中の整流コイルの誘導起電力の正確な算 定である。ここでは, 整流コイルの誘導起電力をべクトル ポテンシャルの時間変化から求めており, 整流中のコイル の変圧器起電力を厳密に考慮している。次は, 同じく整流 方程式に含まれる時々刻々変化するブラシ接触抵抗の正確 な算定である。最後は, 回転速度とともに変化する機械損 の与え方である。特に, 機械損には摺動接触による摩擦損 があり, ベアリング損及び風損と予め分離して求めておく 必要がある。

本論文では, 回転に伴い, ブラシ/整流子の接触面積変化 によって変化するブラシ接触抵抗と機械損 (摩擦損, ベアリ ング損および風損など）を厳密に考慮した新しいユニバー サルモータの過渡特性解析を提案する。ここで, 始動期間 中の過渡電流, 過渡卜ルク, 速度が, 電磁界方程式, 回路 方程式, 運動方程式を連成した有限要素法による解析法 ${ }^{(3)}$ を用いて求められ, 次に, $500 \mathrm{~W}, 2$ 極のユニバーサルモー 夕の実験結果との比較から, 解析法の妥当性が検証されて いる。なお, 始動時の過渡トルクの計算には, 比較的少な いメッシュで高精度のトルク值が求まる Bil 則による方法 を用いた ${ }^{(4)}$ 。 


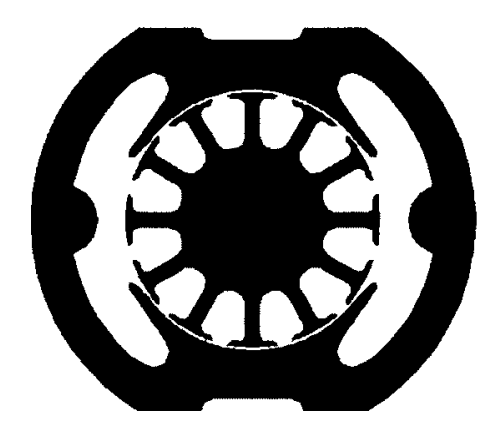

図 1 ユニバーサルモータの断面図

Fig. 1. Cross section of universal motor.

\section{2. 解析方法}

図 1 に本解析に用いたユニバーサルモータの断面図を示 す。一般に, ユニバーサルモータの磁界解析は, 三次元解析 になる。しかし，電動機端部でのコイルの漏れ磁束の影響 を漏れインダクタンスを用いて, 電気回路方程式において考 慮することにより，二次元問題に帰着することができる ${ }^{(5)}$ 。 二次元直交座標系での電磁界の基本方程式を次に示す。

$$
\begin{aligned}
& \frac{\partial}{\partial x}\left(v \frac{\partial A}{\partial x}\right)+\frac{\partial}{\partial y}\left(v \frac{\partial A}{\partial y}\right) \\
& \quad=-J_{0}-J_{s 1}-J_{s 2}-J_{s 3}-J_{s 4}
\end{aligned}
$$

ここで, $A$ : ベクトルポテンシャル,$J_{0}$ : 電機子電流 $i$ の 電流密度, $J_{s 1} \sim J_{s 4}$ : 整流コイルの電流 $i_{s 1} \sim i_{s 4}$ の電流密 度, $v:$ 磁気抵抗率

図 2 に, 本解析で使用のユニバーサルモータのブラシ, 整 流子片及び電機子コイルの配置図を示す。図から，電機子 スロットには，進みコイルと遅れコイルの二つのコイルが 納められていることがわかる。図 3 は，図 2 を回路図で示 したものである。図中の○と口印は，それぞれ電機子コイ ルと整流子片を表し，それらの番号は図 2 に対応したコイ ル番号と整流子片番号である。以下に，ユニバーサルモー タの電圧電流方程式を示す。

$$
\begin{gathered}
e_{f}+e_{a}+\left(r_{a}+r_{f}\right) i+\left(L_{a 0}+L_{f 0}\right) \frac{\partial i}{\partial t}+r_{1} i_{1}+r_{3} i_{6}=v \\
\ldots \ldots \ldots \ldots \ldots \ldots \ldots(2) \\
e_{s 1}+r_{s} i_{s 1}+L_{s 0} \frac{\partial i_{s 1}}{\partial t}-r_{1} i_{1}+r_{2} i_{2}=0
\end{gathered}
$$$$
e_{s 2}+r_{s} i_{s 2}+L_{s 0} \frac{\partial i_{s 2}}{\partial t}-r_{1} i_{4}+r_{2} i_{5}=0
$$$$
e_{s 3}+r_{s} i_{s 3}+L_{s 0} \frac{\partial i_{s 3}}{\partial t}-r_{2} i_{2}+r_{3} i_{3}=0
$$

$$
e_{s 4}+r_{s} i_{s 4}+L_{s 0} \frac{\partial i_{s 4}}{\partial t}-r_{2} i_{5}+r_{3} i_{6}=0
$$

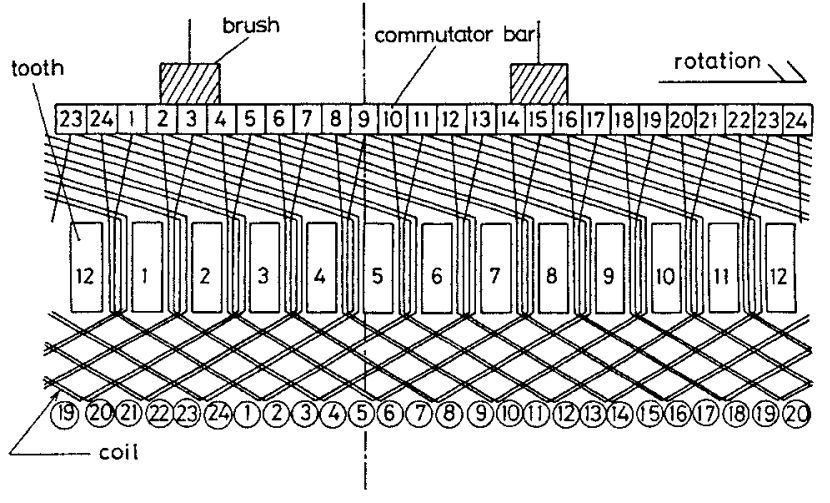

図 2 ブラシ, 整流子片及び電機子コイルの配置

Fig. 2. Arrangement of brushes, commutator bars and coils.

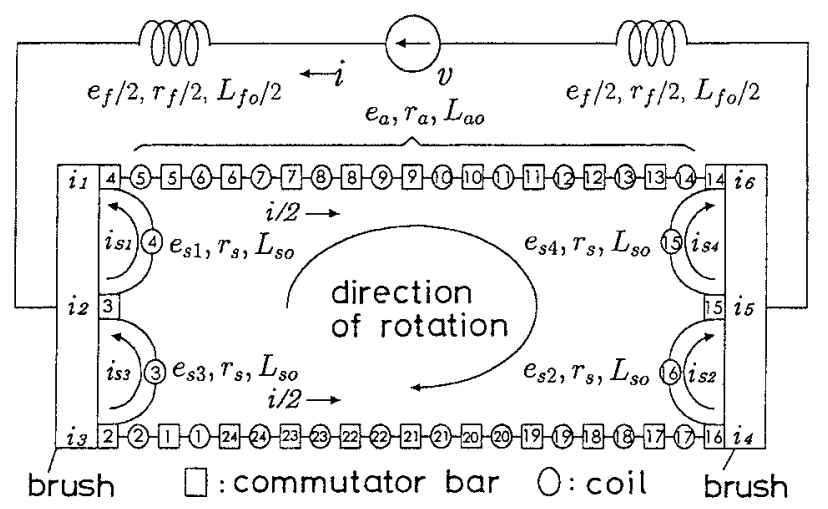

図 3 ユニバーサルモータの回路

Fig. 3. Circuit of universal motor.

$$
\begin{aligned}
& i_{1}=\frac{i}{2}-i_{s 1} \ldots \\
& i_{2}=i_{s 1}-i_{s 3} \ldots \\
& i_{3}=\frac{i}{2}+i_{s 3} \cdots \\
& i_{4}=\frac{i}{2}-i_{s 2} \\
& i_{5}=i_{s 2}-i_{s 4} \\
& i_{6}=\frac{i}{2}+i_{s 4}
\end{aligned}
$$

ここで, $v$ : 端子電圧, $e_{f}, e_{a}$ : それぞれ界磁巻線, 電機 子巻線の誘導起電力, $e_{s 1} \sim e_{s 4}$ : 整流コイルの誘導起電力, $r_{f}, r_{a}, r_{s}$ : それぞれ界磁巻線, 電機子巻線（整流コイルを 除く), 整流コイルの抵抗, $L_{f 0}, L_{a 0}, L_{s 0}$ : それぞれ界磁 巻線, 電機子巻線, 整流コイルのコイル端の漏れインダク タンス, $r_{1}, r_{2}, r_{3}$ : それぞれ整流子片とブラシ間の接触抵 抗 ${ }^{(5)}$

$L_{f 0}, L_{a 0}, L_{s 0}$ は二次元磁界解析では考慮できないコイル 端の漏れインダクタンスであり, ここでは設計值( ${ }^{(6)}$ を用い た。(2) (6) 式の各巻線の誘導起電力 $e$ は, 各巻線に沿った 積分路 $c$ を用いて，次式で表せる。

$$
e=\oint_{c} \frac{\partial A}{\partial t} d s
$$




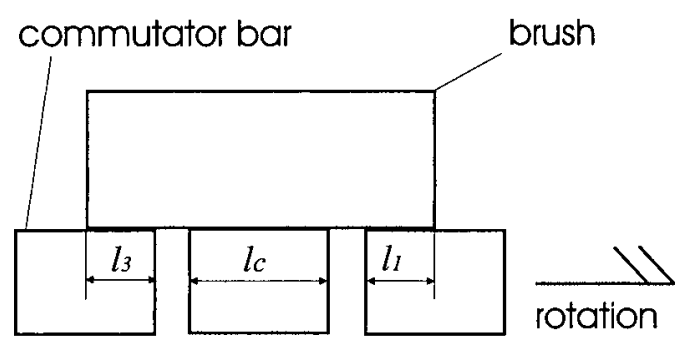

図 4 ブラシと整流子片部分の拡大図

Fig. 4. Arrangement of brush and commutator bars.

(13) 式から明らかなように, 整流中のコイルは変圧器起 電力を含んでいる。な技，図 2 から分かるように，電機子 スロットには 4つのコイルが含まれている。ここで，電機 子コイルの短節度は 0.77 である。次に, 図 2 のブラシと整 流子片の接触部分の拡大図を図 4 に示す。ブラシの整流子 片被覆数は 2 である。 $r_{1}$ はブラシ前端の整流子片とブラシ 間の接触抵抗で, $r_{3}$ はブラシ後端の整流子片とブラシ間の 接触抵抗である。以下に, $r_{1}, r_{2}, r_{3}$ の接触抵抗を示す (5)。

$$
\begin{aligned}
& r_{1}=2 R_{b} \frac{S_{c}}{S_{1}}=2 R_{b} \frac{l_{c}}{l_{1}} \ldots \ldots \\
& r_{2}=2 R_{b} \frac{S_{c}}{S_{c}}=2 R_{b} \frac{l_{c}}{l_{c}}=2 R_{b} \\
& r_{3}=2 R_{b} \frac{S_{c}}{S_{3}}=2 R_{b} \frac{l_{c}}{l_{3}} \ldots \ldots
\end{aligned}
$$

ここで, $R_{b}$ : ブラシの全接触抵抗, $S_{c}$ : 整流子片の全接 触面積, $S_{1}$ : ブラシ前端での整流子片とブラシ間の接触面 積, $S_{3}$ : ブラシ後端での整流子片とブラシ間の接触面積, $l_{c}$ : 整流子片の厚さ, $l_{1}, l_{3}$ : それぞれブラシ前端と後端で の整流子片とブラシの接触長さ（図 4 参照）

(14) (16) 式から，接触抵抗は $R_{b}, l_{c}, l_{1}, l_{3}$ から求まる。 ここで， $R_{b}$ の值は，ブラシ接触電圧降下の V-I 特性（実測 值）が線形であるため一定とした。 $l_{c}$ は設計值（または実 測值）から求まる。 $l_{1}, l_{3}$ の值が回転とともに変化し, 回 転子の位置によって一意的に求まるが，時々刻々の回転子 の位置情報が必要である。本論文では，後述の (22) 式によ り, 任意の時刻での回転子の位置を求めているので, $l_{1}, l_{3}$ を求めることができ，短絡電流による磁界の影響を考慮し た解析が行える特長がある。これにより，始動時の電機子 反作用，磁気飽和，短絡電流による磁界の影響を厳密に考 慮した過渡電流，過渡トルク，速度を求めることができる。

一般に, モー夕の回転運動は, 次式の運動方程式で与え られる(2)。

$$
T=J \frac{\mathrm{d} \omega_{r}}{\mathrm{~d} t}+T_{l}
$$

ここで， $T$ : モータの発生トルク $, J:$ 回転体の慣性モ一 メント, $\omega_{r}$ : 回転体の瞬時の角速度, $T_{l}$ : 負荷卜ルク（機 械損も含める)

$T$ の計算には, 比較的少ないメッシュで高精度のトルク 值が求まる Bil 則による方法を用いた ${ }^{(4)}$ 。さらに， $\omega_{r}$ は回 転角 $\theta$ を用いて，次式で表せる。

$$
\omega_{r}=\frac{\mathrm{d} \theta}{\mathrm{d} t} .
$$

ここで, $\theta:$ 回転角

(18) 式を(17) 式に代入して，整理すると次式を得る。

$$
T=J \frac{\mathrm{d}^{2} \theta}{\mathrm{d} t^{2}}+T_{l}
$$

なお，ここでは時間刻み幅を $\Delta t$ とし, (18) 式右辺の $\mathrm{d} \theta / \mathrm{d} t$, (19) 式右辺の $\mathrm{d}^{2} \theta / \mathrm{d} t^{2}$ の項をそれぞれ前進差分近似して, 時 刻 $t$ の回転角 $\theta_{t}$ を求めている ${ }^{(3)}$ 。すなわち,

$$
\begin{aligned}
& \left.\frac{\mathrm{d} \theta}{\mathrm{d} t}\right|_{t-\Delta t}=\frac{\theta_{t}-\theta_{t-\Delta t}}{\Delta t} \\
& \left.\frac{\mathrm{d}^{2} \theta}{\mathrm{d} t^{2}}\right|_{t-\Delta t}=\frac{\theta_{t}-2 \theta_{t-\Delta t}+\theta_{t-2 \Delta t}}{(\Delta t)^{2}} . \\
& \theta_{t}=\frac{(\Delta t)^{2}}{J}\left(T_{t-\Delta t}-T_{l, t-\Delta t}\right)+2 \theta_{t-\Delta t}-\theta_{t-2 \Delta t}
\end{aligned}
$$

本論文では，時間刻み有限要素法を用いて，(1) (12) 式 と (19) 式を連立して解くことにより, ベクトルポテンシャ ル，電流，回転子角速度を求めている( ${ }^{(3)}$ 。

\section{3. ユニバーサルモータの定常負荷特性}

ここでは, $500 \mathrm{~W}, 2$ 極, $50 \mathrm{~Hz}, 100 \mathrm{~V}, 8.0 \mathrm{~A}, 19200 \mathrm{~min}^{-1}$ のユニバーサルモータを実験機として用いた。

まず，時間刻み幅を決定するために，一定回転速度で運転 するユニバーサルモータの定常負荷特性の計算值と実験值 を比較する。ここで, 時間刻み幅の選択には, 既に文献 (5) でその妥当性が確認されている手順に従った。具体的には, 整流変化を考慮した次式を用いた。

$$
\Delta t=\frac{60}{N \times N_{\text {segment }} \times N_{\text {sample }}}
$$

ここで， $N$ : 毎分あたりの回転数, $N_{\text {segment }}$ : 整流子片の

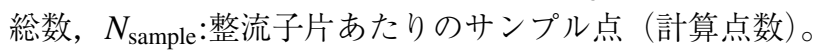

実際に，本論文で用いた值は， $N_{\text {segment }}=24, N_{\text {sample }}=9$ である。定常負荷時の整流電流については, 既に文献 (5) で，補極のないユニバーサルモータでは，遅れコイルの整 流電流が不足整流となることを示した。また，整流電流の 計算值と実験值のよい一致を確認していることから，ここ では, 始動時に扔ける電機子電流のみを示し, 整流電流の 計算結果については省略する。

図 5 に，ユニバーサルモータの定常負荷時の電機子電流 の計算値と実験值を示す。実験は, 定格值に近い AC100 V, $18800 \mathrm{~min}^{-1}$ の定常運転時で行った。ここで使用した時間 刻み幅の值は, $N=18800$ として, $\Delta t \cong 14.8 \mu \mathrm{s}$ であった。 図から，計算值と実験值との一致がよいことがわかる。ま た，電機子電流の計算值と実験值の両方が，電機子反作用 と磁気飽和の影響により，正弦波にはならず，第三次高調 波成分を含む波形になっていることがわかる。したがって， 電磁界方程式と回路方程式の連成解析が妥当で, 時間刻み 幅の選択も妥当であることがわかる。 


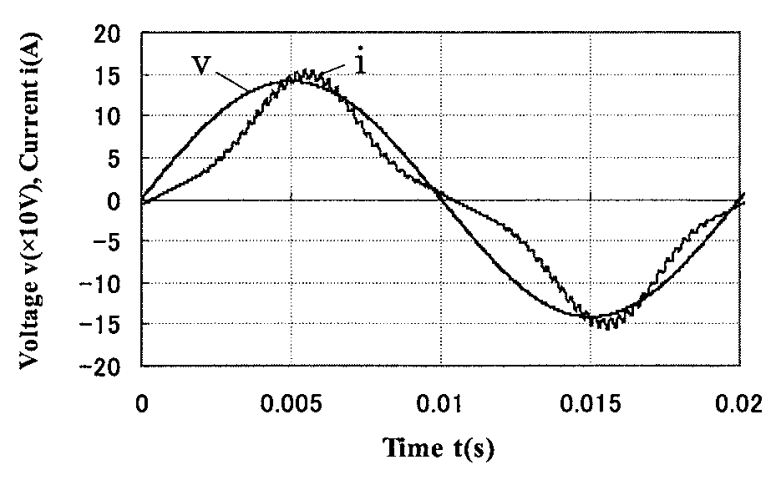

(a) Computed results

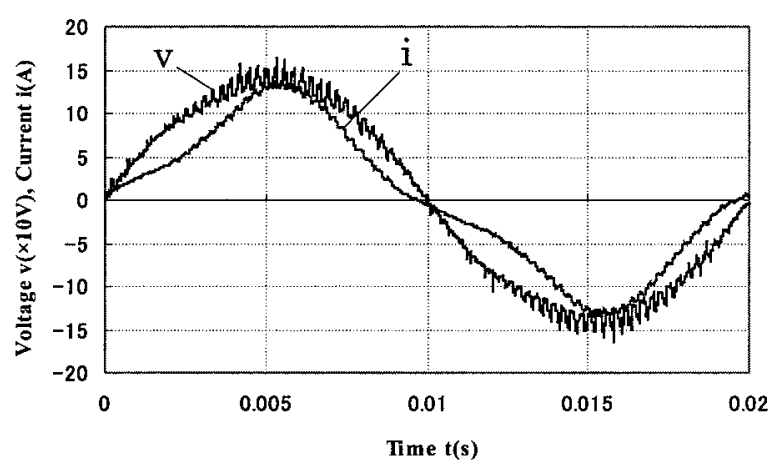

(b) Measured results

図 5 ユニバーサルモータの定常時の電機子電流 Fig. 5. Steady-state armature current versus time at AC100 V and $18800 \mathrm{~min}^{-1}$.

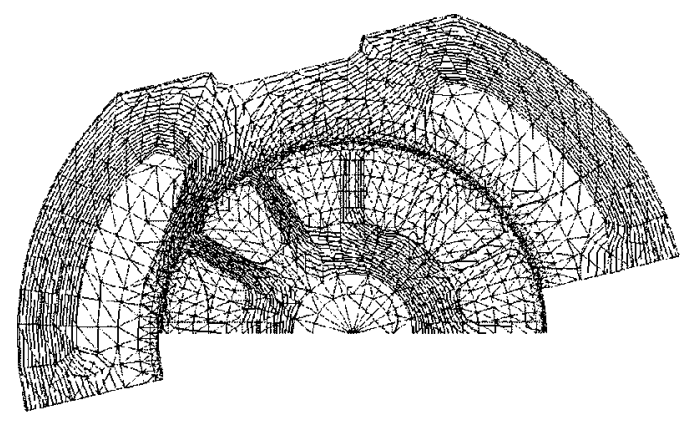

図 6 磁束分布

Fig. 6. Flux distribution at $t=0.0025 \mathrm{~s}$.

図 6 に, 時刻 $t=0.0025 \mathrm{~s}$ で $v=100 \mathrm{~V}$ のときの磁束分 布を示す。

\section{4. 始動特性}

ここでは，機械損の影響を明らかにするために，無負荷 での速度応答特性を示す。したがって，(19) 式の負荷トル ク $T_{l}$ は，機械損によるもののみである。ユニバーサルモー 夕の機械損は，さらに摩擦損と風損に大別できる。

図 7 に, 摩擦損と風損の測定から求めた摩擦によるトル ク $T_{b}$ と風損によるトルク $T_{w}$ をそれぞれ示す。図で，プ ロット点は実測值を示し, 実線はその近似曲線（一次式） を表す。ここでは，風損によるトルクを直線近似で求めた ため， $16000 \mathrm{~min}^{-1}$ で，傾きが変わっているように見える

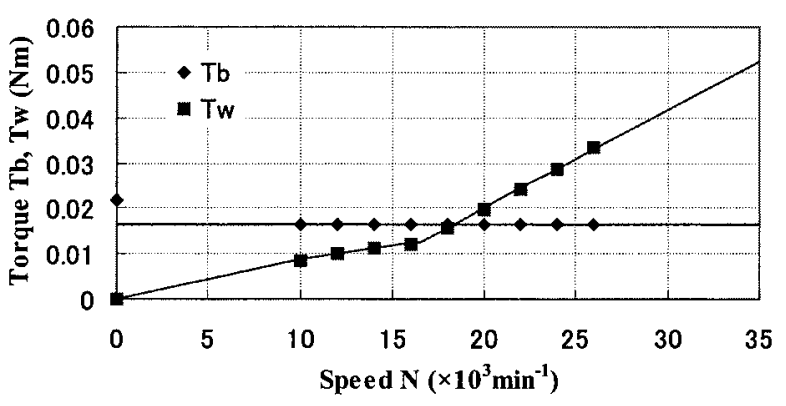

図 7 摩擦損と風損によるトルク

Fig. 7. Torques due to friction and widage losses.

が，理想的には，回転速度の自乗で変化するものと考えら れる。事実， $14000 \mathrm{~min}^{-1}$ 以上では回転速度の自乗曲線で 近似できることがわかっている。これは，14000 $\mathrm{min}^{-1}$ 未 満では風損そのものが小さくなるため, 風損測定值からの 風損卜ルクの正確な算定が難しくなるためと考えられる。 なお, 動摩擦トルクは一定とし, 最大静止摩擦トルクを動 摩擦トルクの 1.3 倍（実測值）とした。ここでは，機械損 を $T_{l}=T_{b}+T w$ として取り扱い, 回転制動係数による項 を省略している。以下, 直流電源と交流電源に対するユニ バーサルモータの始動特性の計算結果と実験結果の比較を 示し，本解析法の妥当性を明らかにする。

図 8〜図 10 に, 直流電源を用いた場合 (DC30V) の工 ニバーサルモータの始動特性を示す。

図 8 に, 電機子電流の計算值と実験值の比較を示す。眓か ら, 計算值と実験值とは, よく一致していることがわかる。

図 9 に速度応答特性の計算值と実験值の比較を示す。始 動直後において, 実験值の立ち上がりが, 計算值に比較し て遅いことがわかる。これは，回転数計測に用いた FVコ ンバータがペリオマチック方式 (7) (パルス入力による周波 数演算）によるため, 始動直後に最初のパルスが入力され ても, 次のパルスが来るまでの比較的長い時間, 出力が現 れない (回転数が零) という現象が起きることによる。こ のことを考慮すれば, 計算值と実験值の一致はよく, 本解 析法の妥当性が確認できる。

図 10 にトルクの計算值を示す。トルク波形は, 始動直 後のように電機子電流が大きく, 磁気飽和が大きい場合を 除いて, 電機子電流の自乗の波形になると考えられる。ま た, 図から, 電機子スロットによるパーミアンス不均一に 基づくトルクリプルが小さいことがわかる。これは, 始動 直後の約 $0.1 \mathrm{~s}$ 間を除いて, 電機子電流が約 $3 \mathrm{~A}$ 以下と小さ いためで, 図 5 の定常時の電機子電流においても, 約 $3 \mathrm{~A}$ 以下で電機子スロットによるパーミアンス不均一に基づく 電流リプルの影響が小さいことから推察できる。なお，こ こで使用した時間刻み幅の值は, $t=2 \mathrm{~s}$ の回転速度の計算 值 $13800 \mathrm{~min}^{-1}$ を超える $N=16000$ として, $\Delta t \cong 21.4 \mu \mathrm{s}$ であった。

次に，交流電源を用いた場合のユニバーサルモータの始 動特性を図 11〜図 16 に示す。 


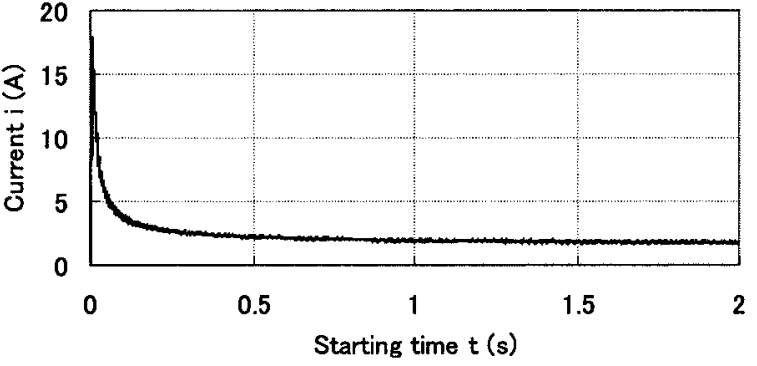

(a) Computed results

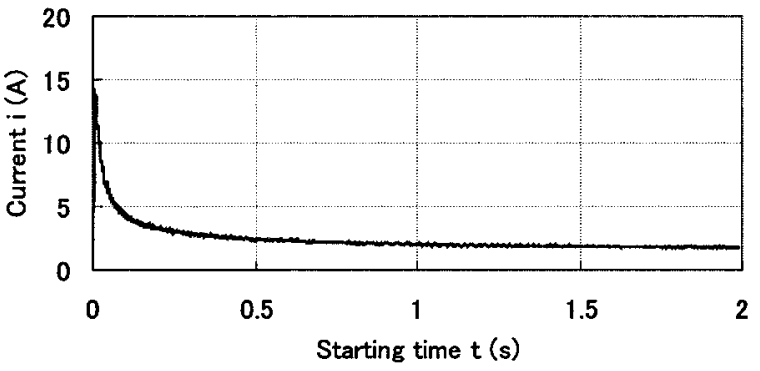

(b) Measured results

図 8 始動時の電機子電流 (DC30 V)

Fig. 8. Armature current during run-up at DC30 V.

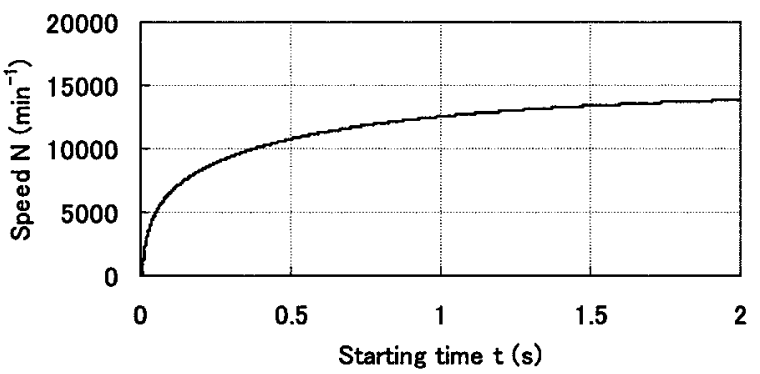

(a) Computed results

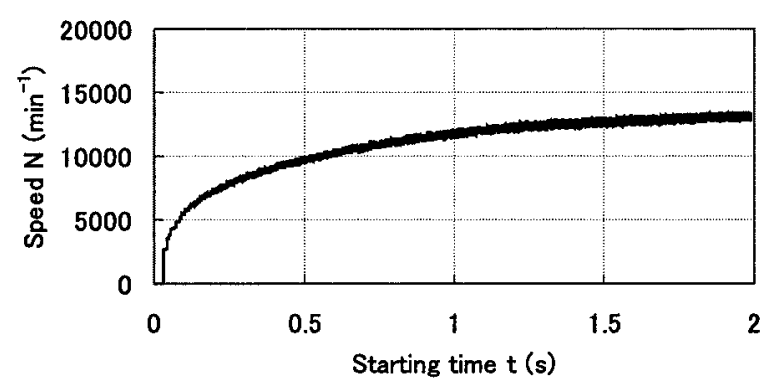

(b) Measured results

図 9 始動時の速度応答 (DC30 V)

Fig. 9. Speed during run-up at DC30 V.

図 11〜図 13 は，端子電圧が AC30 V の場合である。こ れは，先の DC30 V の場合の始動特性と比較するためのも のである。

図 11 に，電機子電流の計算值と実験值の比較を示す。 DC30 V の図 8 と同様に, 電機子電流の計算值と実験值と は,よく一致していることがわかる。

図 12 に速度応答特性の計算值と実験值の比較を示す。 図 9 と同様に, 始動直後において, 実験值の立ち上がりが,

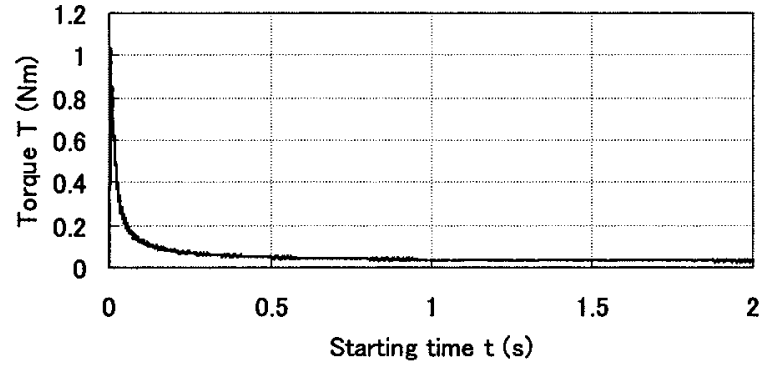

図 10 始動時のトルク（DC30 V)

Fig. 10. Computed torque during run-up at DC30 V.

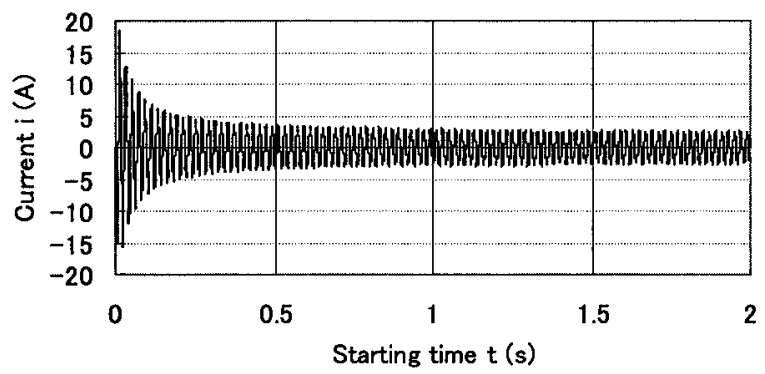

(a) Computed results

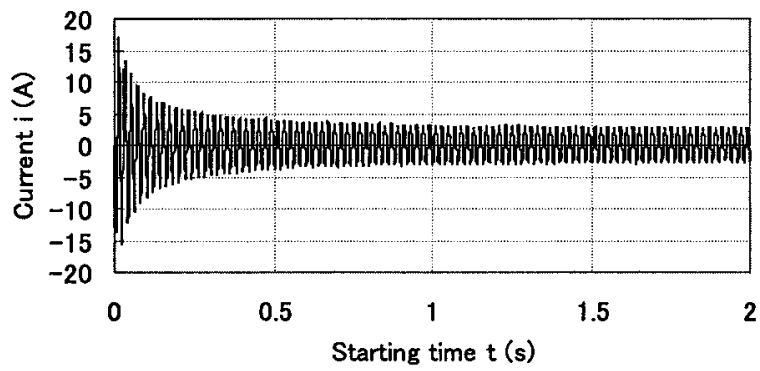

(b) Measured results

図 11 始動時の電機子電流（AC30 V)

Fig. 11. Armature current during run-up at AC30 V.

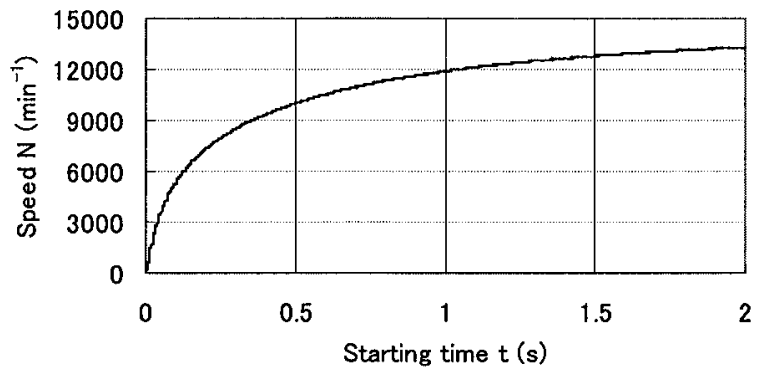

(a) Computed results

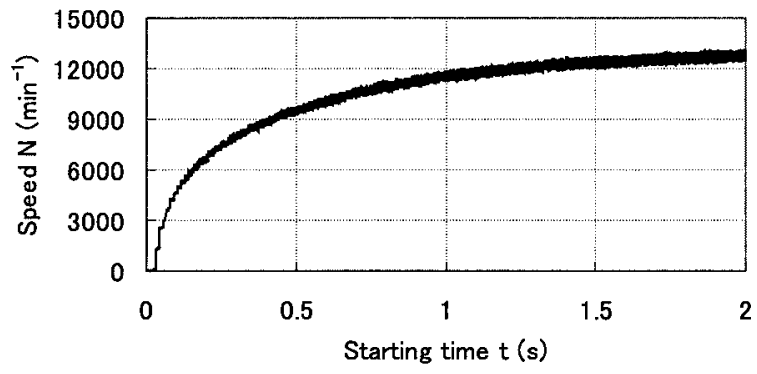

(b) Measured results

図 12 始動時の速度応答 $(\mathrm{AC} 30 \mathrm{~V})$

Fig. 12. Speed during run-up at AC30 V. 


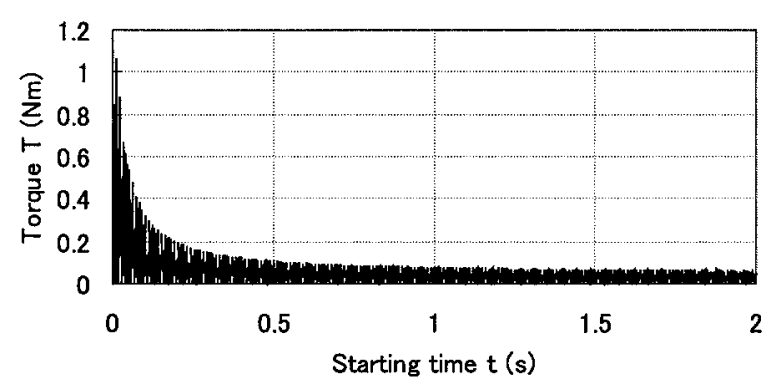

図 13 始動時のトルク (AC30 V)

Fig. 13. Computed torque during run-up at $\mathrm{AC} 30 \mathrm{~V}$.

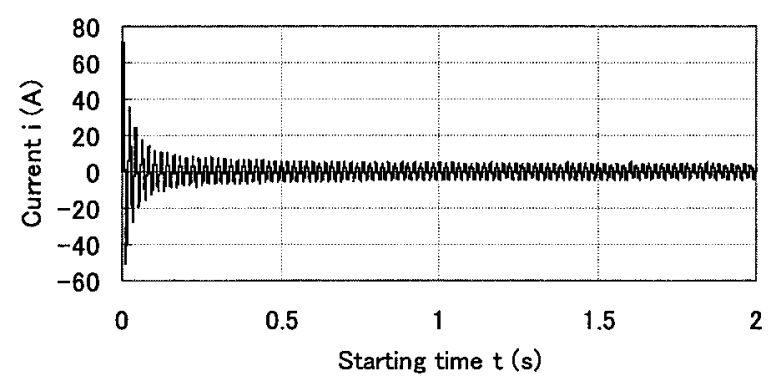

(a) Computed results

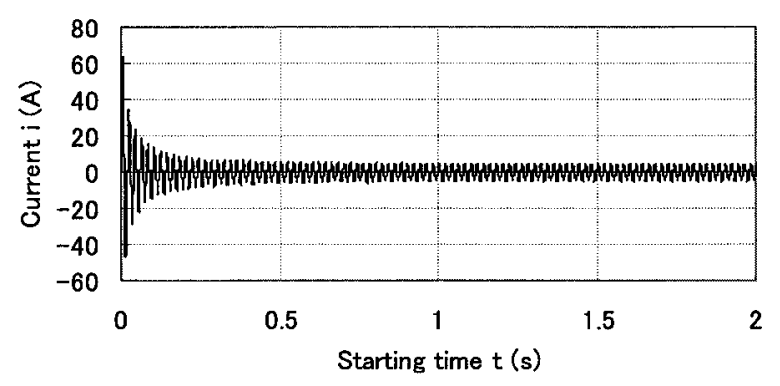

(b) Measured results

図 14 始動時の電機子電流 $(\mathrm{AC} 90 \mathrm{~V})$

Fig. 14. Armature current during run-up at AC90 V.

計算值に比較して遅いことがわかる。これは図 9 のところ で既に述べた理由によるものである。このことを考慮すれ ば, 計算值と実験值の一致はよく, 交流電源においても, 本 解析法の妥当性が確認できる。

図 13 にトルクの計算值を示す。電動機に正弦波の交流 電圧を印加しているので，図 10 の直流電源のトルク波形 と比較して，トルク波形には，大きな脈動卜ルクが含まれ ていることがわかる。ここで使用した時間刻み幅の值には, 直流電源の DC $30 \mathrm{~V}$ の場合に同じ $\Delta t \cong 21.4 \mu \mathrm{s}$ を用いた。

図 14〜 図 16 は，端子電圧が AC90V の場合である。 $\mathrm{AC} 90 \mathrm{~V}$ の始動特性は, 先の AC30 V の場合に比較して, 定格電圧の $\mathrm{AC} 100 \mathrm{~V}$ に近く, 電機子電流も大きく, 高速回 転になっている。実験では, AC $90 \mathrm{~V} て ゙$ 既に, 始動直後の電機 子電流が $60 \mathrm{~A}$ を超え, $t=2 \mathrm{~s}$ での回転速度も $31000 \mathrm{~min}^{-1}$ を超えたので， $\mathrm{AC} 100 \mathrm{~V}$ の直入れ始動は行わなかった。

図 14 に，電機子電流の計算値と実験值の比較を示す。 $\mathrm{AC} 30 \mathrm{~V}$ の図 11 と同様に, 電機子電流の計算值と実験值と は，よく一致していることがわかる。

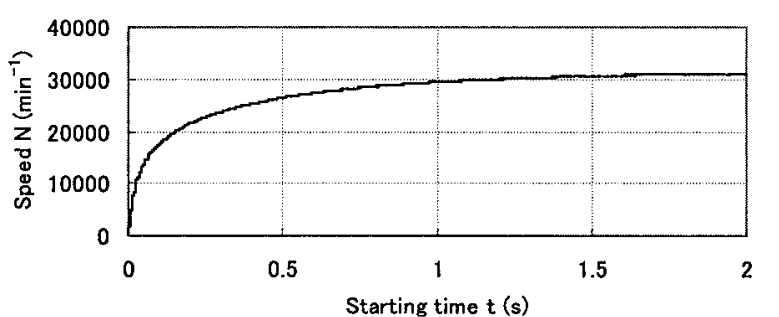

(a) Computed results

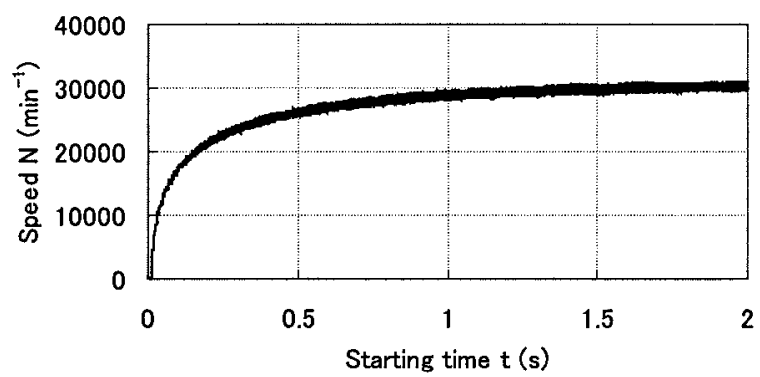

(b) Measured results

図 15 始動時の速度応答 $(\mathrm{AC} 90 \mathrm{~V})$

Fig. 15. Speed during run-up at AC90 V.

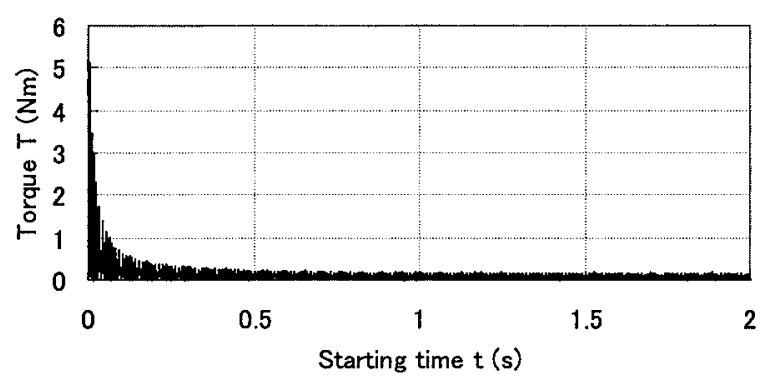

図 16 始動時のトルク (AC90 V)

Fig. 16. Computed torque during run-up at AC90 V.

図 15 に，速度応答特性の計算值と実験值を示す。図 9, 図 12 と同様に, 始動直後に扔いて, 実験值の立ち上がりが, 計算值に比較して遅いことがわかる。これは図 9 のところ で既に述べた理由によるものである。このことを考慮すれ ば，計算値と実験值の一致はよく，定格電圧近くにおいて も，本解析法の妥当性が確認できる。なお， $t=2 \mathrm{~s}$ の回転 速度は，計算值と実験值は等しく $31100 \mathrm{~min}^{-1}$ であった。

図 16 はトルクの計算值である。トルク波形は，AC30 V のトルク波形同様, 脈動卜ルクが大きいことがわかる。なお, ここで使用した時間刻み幅の值は, $t=2 \mathrm{~s}$ の回転速度の計 算值 $31100 \mathrm{~min}^{-1}$ を超える $N=35000$ として, $\Delta t \cong 7.94 \mu \mathrm{s}$ であった。

最後に，短絡電流を考慮しない場合，即ち，短絡電流 $i_{s 1} \sim i_{s 4}$ (図 3 参照) の全てを零として, 短絡回路の電 圧電流方程式 (3) (6) 式を省略したときの速度応答特性の 計算値を, 短絡電流を考慮した場合のものと比較して, 図 17 に示す。図から, 短絡電流を考慮しない速度応答特性は, 考 慮したものに比較して計算值が小さく, $t=1.2 \mathrm{~s}$ において $6.1 \%$ もさくなっている。これは短絡電流もトルクに寄与 


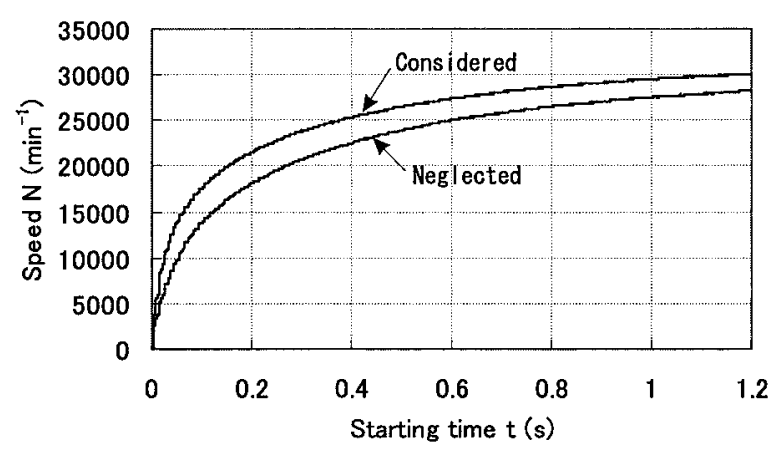

図 17 短絡電流の有無による速度応答の比較 $(\mathrm{AC} 90 \mathrm{~V})$

Fig. 17. Comparison between computed speed curves with and without short-circuited coil currents during runup at $\mathrm{AC} 90 \mathrm{~V}$.

しており，短絡電流を無視すると推進トルクが小さくなる ためである。ここでは, ページ数の関係で速度応答特性の みを示したが，短絡電流を考慮した電機子電流波形は実験 值のものによく一致し，これを考慮しない電機子電流は実 験值には見られない凹凸を多く含んだ波形となり，実験值 のものと相違することがわかっている。以上のように，短 絡電流を考慮することにより, 正確な始動特性解析が行え たものと確信している。

\section{5. むすび}

本論文では, 回転とともに変化するブラシ接触抵抗と機械 損を考慮した新しいユニバーサルモータの過渡特性解析を 提案した。 $500 \mathrm{~W}, 2$ 極, $50 \mathrm{~Hz}, 100 \mathrm{~V}, 8.0 \mathrm{~A}, 19200 \mathrm{~min}^{-1}$ のユニバーサルモータの始動特性の計算結果と実験結果は よく一致し，本解析法の妥当性が検証できた。また，実機 と解析との比較を定常特性・過渡特性（始動特性）につい て行っており, その一致の良さから, 今後の高性能化設計 において, 本解析が実機試作の省略を可能にすると考えら れる。

終わりに，本研究にあたって全面的なご援助を戴いた日 立工機株式会社 開発研究所所長の篠原 茂氏に厚く御礼 申し上げる。

(平成 16 年 10 月 13 日受付, 平成 17 年 7 月 22 日再受付)
(5) K. Kurihara, T. Kadode, T. Kubota, G. Wakui, S. Suzuki, S. Sakamoto, and S. Shinozaki: "Commutation analysis of universal motors including arc voltages", Proc. JIASC 1995, Vol.1, pp.277-280 (1995) (in Japanese) 栗原和美 · 角出 巧 · 久保田朋次 · 湧井源二郎 - 鈴木 俊 · 坂本眞 一・篠崎俊栄：「アーク電圧を考慮した単相直巻整流子電動機の整 流解析」, 平 7 電気学会産業応用部門大会, 1, pp.277-280 (1995-8)

（6）執行岩根：電気機械設計論 1 , 丸善 (1950)

（7）ペリオマチック方式については, http://www.cocores.co.jp/japanese/tech/ を参照のこと。

栗 原 和 美 (上級会員) 1978 年 3 月茨城大学大学院工学研

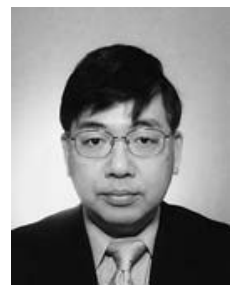
究科電気工学専攻修士課程修了。同年 4 月（株） 日立製作所入社。1981 年 4 月茨城大学助手, 同講 師, 同助教授を経て, 2004 年 4 月同教授, 現在に至 る。1999 年 6 月から 2000 年 3 月まで, Memorial University の客員研究員。博士 (工学)。主として, 有限要素法を用いた回転機の磁界解析, 永久磁石 同期電動機，整流子電動機の研究に従事。1990, 1991 年電気学会論文発表賞受賞。日本応用磁気学会, IEEE 会員。

坂 本 負 - (正員) 1950 年 4 月 28 日生。 1973 年 3 月東北

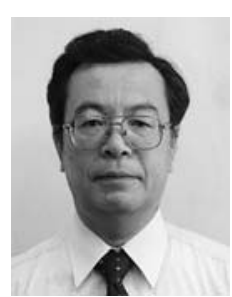
大学理学部物理第 2 学科卒業。1975 年 3 月同大 学大学院修士課程修了。同年 4 月日立工機（株） 入社。現在, 同社 開発本部 開発研究所 主任研 究員。主として整流子モータおよびその整流の研 究に従事。 